\title{
PEMAHAMAN SISWA TENTANG APLIKASI KONSEP SUHU DAN KALOR YANG BERKAITAN DENGAN KOMPUTER
}

\author{
Zainul Mustofa \\ SMK Al Munawwariyyah, Jalan Sudimoro No. 9, Bululawang, Malang, Jawa Timur \\ E-mail: zainulmustofa1993@yahoo.com
}

\begin{abstract}
Abstrak
Berbeda dengan level pendidikan menengah lainnya, pembelajaran fisika di SMK Teknik memiliki kewajiban lebih yaitu untuk mengintegrasikan konsep-konsep fisika dalam bidang keahliannya. Tujuan utama penelitian ini adalah untuk mengetahui bagaimana pemahaman siswa terkait aplikasi konsep suhu dan kalor yang berkaitan dengan komputer. Jenis penelitian ini adalah penelitian deskriptif kuantitatif dengan metode studi kasus. Subjek penelitian terdiri atas 36 siswa teknik komputer dan jaringan (TKJ), SMK Al Munawwariyyah Tahun Pelajaran 2018/2019. Hasil penelitian menunjukkan bahwa sebagian besar siswa telah memahami aplikasi konsep suhu dan kalor yang berkaitan dengan komputer lebih dari $80 \%$. Aplikasi konsep yang telah mereka pahami antara lain persamaan kalor dan maknanya, jenis perpindahan kalor dan dampaknya, dan identifikasi permasalahan komputer yang berkaitan dengan kalor (troubleshooting).
\end{abstract}

Kata kunci: pemahaman konsep, aplikasi suhu dan kalor, komputer

\begin{abstract}
In contrast to other secondary education levels, learning physics at the Technical Vocational School has more obligation, namely to integrate the concepts of physics in the field of expertise. The main purpose of this study is to find out how students' understanding of the application of the concept of temperature and heat associated with komputers. This type of research is quantitative descriptive research. The research subjects consisted of 36 komputer and network engineering (TKJ) students, Al Munawwariyyah Vocational School 2018/2019. The results showed that most students had understood the application of the concept of temperature and heat associated with komputers for more than $80 \%$. Application concepts that they have understood include the heat equation and its meaning, the type of heat transfer and its effects, and the identification of komputer problems related to heat (troubleshooting).
\end{abstract}

Keywords : concept understanding, temperature and heat application, komputer

\section{PENDAHULUAN}

Memahami suatu konsep fisika yang melandasari dunia teknik mutlak diperlukan oleh orang yang bergelut di dalamnya. Siswa SMK jurusan keteknikan secara umum tentu akan menempuh mata pelajaran fisika sebagai dasar bidang keahliannya (Kemdikbud, 2018). Fisika memiliki peranan penting dalam mendukung pemahaman yang utuh terkait kompetensi keahlian yang dipelajari siswa. Konsep-konsep fisika telah digunakan secara lebih luas dalam masing-masing bidang kompetensi yang ada di keteknikan. Fisika berperan penting dalam tahap analisis masalah, merancang solusi permasalahan, hingga melaksanakan solusi tersebut.

Pentingnya fisika sebagai landasan teori dari sekian banyak praktek di bidang keteknikan pada siswa menjadian penelitian pemahaman konsep fisika menjadi trend hingga saat ini. Hal ini dapat ditelusuri pada berbagai jurnal yang meneliti tentang pemahaman konsep fisika. Ada yang membahas tentang kesulitan konsep siswa seperti Mustofa et al. (2016) yang membahas kesulitan konsep energi dan Mustofa (2018) yang membahas kesulitan konsep elastisitas bahan. Ada yang membahas pembelajaran untuk meningkatkan pemahaman konsep seperti Mustofa (2019) yang memanfaatkan pembelajaran berbasis penemuan, Triyuni (2016) yang memanfaatkan pembelajaran berbasis masalah, dan Mustofa (2016) yang 
memanfaatkan pembelajaran kooperatif. Selain itu, juga ada yang membahas media pembelajaran yang dapat dimanfaatkan untuk meningkatkan pemahaman konsep fisika siswa seperti Mustofa (2018) yang memanfaatkan multimedia interaktif.

Memahami suatu konsep fisika yang melandasari dunia teknik mutlak diperlukan oleh orang yang bergelut di dalamnya. Siswa SMK jurusan keteknikan secara umum tentu akan menempuh mata pelajaran fisika sebagai dasar bidang keahliannya (Kemdikbud, 2018). Fisika memiliki peranan penting dalam mendukung pemahaman yang utuh terkait kompetensi keahlian yang dipelajari siswa. Konsep-konsep fisika telah digunakan secara lebih luas dalam masing-masing bidang kompetensi yang ada di keteknikan. Fisika berperan penting dalam tahap analisis masalah, merancang solusi permasalahan, hingga melaksanakan solusi tersebut.

Pentingnya fisika sebagai landasan teori dari sekian banyak praktek di bidang keteknikan pada siswa menjadian penelitian pemahaman konsep fisika menjadi trend hingga saat ini. Hal ini dapat ditelusuri pada berbagai jurnal yang meneliti tentang pemahaman konsep fisika. Ada yang membahas tentang kesulitan konsep siswa seperti Mustofa et al. (2016) yang membahas kesulitan konsep energi dan Mustofa (2018) yang membahas kesulitan konsep elastisitas bahan. Ada yang membahas pembelajaran untuk meningkatkan pemahaman konsep seperti Mustofa (2019) yang memanfaatkan pembelajaran berbasis penemuan, Triyuni (2016) yang memanfaatkan pembelajaran berbasis masalah, dan Mustofa (2016) yang memanfaatkan pembelajaran kooperatif. Selain itu, juga ada yang membahas media pembelajaran yang dapat dimanfaatkan untuk meningkatkan pemahaman konsep fisika siswa seperti Mustofa (2018) yang memanfaatkan multimedia interaktif.

Salah satu materi yang penting bagi siswa teknik adalah suhu dan kalor. Suhu dan kalor memiliki pemanfaatan yang luas dalam bidang keteknikan terutama berkaitan dengan sistem termodinamika, sistem pendingin, dan sirkulasi udara dalam suatu ruangan (Firmansyah, 2009). Materi suhu dan kalor di SMK teknik berbeda cakupan dan luasan pembahasan dengan sekolah menengah pada umumnya. Luasan cakupan ini bergantung ruang lingkup dari kompetensi keahlian yang ditekuni. Menjadi tantangan tersendiri bahwa guru fisika di jurusan teknik yang berbeda harus mengerti bagian-bagian konsep mana yang harus lebih ditekankan. SMK bidang keahlian teknik komputer dan informatika misalnya, memanfaatkan konsep suhu dan kalor dalam merancang dan menganalisis sistem pendingin processor, aliran kalor dalam CPU, dan rancangan casing CPU yang efektif dan efisien untuk menjaga kinerja CPU tetap optimal (Budi, Hendradjit, \& Budiman, 2010).

Nyatanya, pentingnya konsep suhu dan kalor belum diikuti pemahaman yang baik secara umum. Hal ini dapat ditelusuri dari berbagai laporan jurnal ilmiah yang menyatakan bahwa materi suhu dan kalor merupakan materi yang cukup sulit dan sering kali menjadi momok bagi siswa sehingga menimbulkan berbagai miskonsepsi pada diri siswa (Alwan, 2011; Musdar, 2018). Setidaknya terdapat beberapa alasan terkait hal itu yang dihadapi oleh siswa secara umum dan terkhusus pada siswa SMK AI Munawwariyyah dalam pembelajaran suhu dan kalor dalam bidang komputer. Pertama, materi suhu merupakan materi yang abstrak, sehingga siswa kesulitan untuk menginderakan. Kedua, Konsep kalor memiliki banyak faktor yang mempengaruhi dan masing-masing faktor tidak boleh dihilangkan begitu saja, sehingga siswa harus memahami semua faktor secara keseluruhan. Ketiga, ketika pembelajaran di kelas, sering kali siswa membawa pemahamannya di kehidupan sehari-hari yang dimungkinkan bertentangan dengan konsep suhu dan kalor yang dipahami oleh ahli.

Permasalahan di atas merupakan kesulitan-kesulitan yang dialami siswa secara umum tentang konsep suhu dan kalor. Sedangkan penelitian yang membahas pemahaman siswa SMK bidang keahlian teknik secara umum berkaitan dengan suhu dan kalor yang terintegrasi dengan bidang keahliannya masih belum ada. Terlebih lagi, penelitian yang membahas tentang pemahaman siswa SMK bidang keahlian teknik komputer dan informatika yang berkaitan dengan suhu kalor masih belum ada. Padahal penggunaan komputer hingga saat ini sangat luas. Tentunya, kebutuhan akan ahli terkait alat elektronik yang satu ini sangat besar. Serta penguasaan kompetensi keahlian yang baik tentu membutuhkan dasar bidang keahliana seperti konsep suhu dan kalor yang baik pula sebagai bekal analisis permasalahan komputer (troubleshooting). 
Berlandaskan latar belakang yang telah dipaparkan di atas, maka jelas bahwa eksplorasi pemahaman siswa terkait konsep suhu dan kalor yang terintegrasi dengan keteknikan di SMK perlu untuk diteliti lebih lanjut. Oleh karena itu, penelitian ini bertujuan untuk mengetahui seberapa jauh pemahaman siswa terkait konsep suhu dan kalor yang terintegrasi dalam bidang keahliannya. Pada penelitian ini pula akan dibahas berbagai konsep dasar yang penting dalam bidang teknik komputer dan informatika.

\section{METODE}

Penelitian ini adalah penelitian studi kasus dengan pendekatan deskriptif kuantitatif. Penelitian deskriptif merupakan bagian dari penelitian kuantitatif yang penting dalam bidang pendidikan untuk menjelaskan fenomena peserta didik (Gall, Gall, \& Borg, 2003). Subjek penelitian terdiri atas 36 siswa kompetensi keahlian teknik komputer dan jaringan, SMK Al Munawwariyyah, Bululawang, Malang. Penelitian dilaksanakan pada semester genap tahun pelajaran 2018/2019. Perlu diketahui, bahwa pembelajaran yang dilakukan di kelas merupakan pembelajaran discovery learning dengan pendekatan saintifik. Pada sesi pembelajaran di kelas, siswa diajak mulai melihat fakta dan fenomena alam, dan, mengobservasi permasalahan dalam bidang komputer. Selanjutnya siswa diajak untuk melakukan praktikum tentang konsep-konsep suhu dan kalor baik yang bersifat umum (dipelajari di SMP maupun SMA) maupun yang terintegrasi dengan kompetensi keahliannya.

Instrumen penelitian yang digunakan pada penelitian ini adalah soal pilihan ganda berjumlah 14 butir soal. Instrumen soal dikembangkan oleh guru secara mandiri dengan bantuan guru Bahasa. Setelah butir soal siap, dilakukan uji empiris kepada 69 siswa. Melalui uji empiris dinyatakan bahwa instumen soal semuanya valid dengan nilai reliabilitas sebesar 0,79 yang masuk kategori reliabel. Ini artinya instrumen soal bersifat ajeg dan dapat mengukur apa yang diukur yaitu tentang aplikasi konsep suhu dan kalor dalam bidang komputer. Indikator butir soal dan konsep dasar yang diujikan pada instrumen dapat dilihat pada Tabel 1.

Tabel 1. Indikator butir soal dan konsep yang diujikan

\begin{tabular}{|c|c|c|}
\hline $\begin{array}{l}\text { Nomor } \\
\text { soal }\end{array}$ & Indikator Soal & $\begin{array}{l}\text { Konsep } \\
\text { diujikan }\end{array}$ \\
\hline $1 \& 2$ & $\begin{array}{l}\text { Mengkonversi skala suhu yang sering } \\
\text { digunakan dalam bidang komputer }\end{array}$ & $\begin{array}{l}\text { Suhu dan konversi } \\
\text { skalanya }\end{array}$ \\
\hline $3 \& 4$ & $\begin{array}{l}\text { Menentukan arah perpindahan kalor } \\
\text { antara sistem dan lingkungan }\end{array}$ & Kalor \\
\hline 5 & $\begin{array}{l}\text { Menentukan bahan heatsink yang paling } \\
\text { tepat untuk menyerap kalor }\end{array}$ & Bahan konduktif \\
\hline 6 & $\begin{array}{l}\text { Menentukan proses fisika yang terjadi } \\
\text { pada sistem processor yang overheating }\end{array}$ & Pemuaian \\
\hline 7 & $\begin{array}{l}\text { Menganalisis hubungan antar besaran- } \\
\text { besaran pada persamaan } Q=m c \Delta T\end{array}$ & Kalor \\
\hline $8,9, \& 10$ & $\begin{array}{l}\text { Menentukan jenis perpindahan kalor } \\
\text { yang terjadi pada suatu fenomena dalam } \\
\text { bidang komputer }\end{array}$ & Perpindahan kalor \\
\hline 11 & $\begin{array}{l}\text { Menganalisis jenis bahan yang paling } \\
\text { baik untuk mentransfer kalor }\end{array}$ & Bahan konduktif \\
\hline 12 & $\begin{array}{l}\text { Menganalisis berbagai perpindahan } \\
\text { kalor yang terjadi pada komputer dan } \\
\text { dampaknya }\end{array}$ & $\begin{array}{l}\text { Perpindahan kalor } \\
\text { dan dampaknya }\end{array}$ \\
\hline 13 & $\begin{array}{l}\text { Mengevaluasi suatu permasalahan } \\
\text { komputer yang berkaitan dengan konsep } \\
\text { kalor menggunakan ilmu troubleshooting }\end{array}$ & Troubleshooting \\
\hline 14 & $\begin{array}{l}\text { Menghitung besarnya daya kalor yang } \\
\text { dipindahkan melalui lapisan pasta } \\
\text { processor }\end{array}$ & Daya konduktivitas \\
\hline
\end{tabular}


Data hasil jawaban siswa di ujian akhir bab dianalisis secara deskriptif kuantitatif. Selanjutnya jawaban siswa yang benar dihitung presentasenya. Beberapa konsep akan dibahas dengan memperhatikan presentase jawaban pada masing-masing pilihan. Analisis dilanjutkan dengan memperkirakan pemahaman siswa berdasarkan pilihan jawaban tersebut. Pilihan jawaban dibuat secara hipotetik dalam pembuatannya. Melalui analisis ini, didapatkan bagaimana pemahaman siswa pada konsep suhu dan kalor yang berkaitan dengan komputer.

\section{HASIL DAN PEMBAHASAN}

\section{Pemahaman Siswa Terkait Konsep Suhu dan Kalor dalam Bidang Komputer}

Berdasarkan data hasil ujian akhir bab diperoleh presentase jawaban benar tiap butir soal. Hasil analisis dapat dilihat pada Tabel 2. Berdasarkan data Tabel 2, nampak bahwa hampir semua konsep telah dikuasai sebagian besar siswa, hanya konsep pada butir soal nomor 6 dan 11 yang dikuasai kurang dari $75 \%$ dari rata-rata standar ketuntasan siswa. Butir soal tersebut membahas tentang prinsip pemuaian yang terjadi pada processor akibat overheating dan menganalisis bahan yang sesuai dan terbaik untuk transfer kalor dari processor ke heatsink. Nilai yang tergolong tinggi menunjukkan bahwa pemahaman siswa secara umum sudah sangat baik dengan nilai rata-rata diatas 80 dari skala 100. Hal ini secara tidak langsung juga menunjukkan bahwa pembelajaran berbasis penemuan dengan pendekatan saintifik cocok untuk pembelajaran suhu dan kalor serta aplikasinya dalam bidang komputer.

Tabel 2. Presentase Jawaban Benar pada masing-masing butir soal

\begin{tabular}{ccc}
\hline $\begin{array}{c}\text { Butir } \\
\text { soal }\end{array}$ & $\begin{array}{c}\text { Jawaban } \\
\text { Benar }\end{array}$ & Presentase \\
\hline 1 & 36 & $100,0 \%$ \\
2 & 35 & $97,2 \%$ \\
3 & 33 & $91,6 \%$ \\
4 & 32 & $88,8 \%$ \\
5 & 31 & $86,1 \%$ \\
6 & 14 & $38,8 \%$ \\
7 & 29 & $80,5 \%$ \\
8 & 33 & $91,6 \%$ \\
9 & 36 & $100,0 \%$ \\
10 & 27 & $75,0 \%$ \\
11 & 25 & $69,4 \%$ \\
12 & 28 & $77,7 \%$ \\
13 & 32 & $88,8 \%$ \\
14 & 33 & $91,6 \%$ \\
\hline
\end{tabular}

Penerapan pembelajaran berbasis penemuan (Discovery learning) dalam pembelajaran suhu dan kalor terbukti efektif dengan pencampaian pemahaman siswa pada setiap butir soal rata-rata $80 \%$. Hasil ini sejalan dengan penelitian Mustofa (2019) yang menunjukkan bahwa pembelajaran discovery learning berbantuan e-learning dapat meningkatakan kemampuan siswa dalam menguasai konsep dan aplikasinya secara signifikan. Hal ini dikarenakan pembelajaran discovery learning menuntun siswa untuk lebih aktif dalam proses pembelajaran dengan keterlibatannya dalam proses penemuan informasi di hampir seluruh jenjang pendidikan (Yuliana, 2018).

\section{Pemahaman Siswa Tentang Persamaan Kalor dan Maknanya}

Butir soal untuk mengakses pemahaman siswa terkait persamaan kalor dan maknanya tersaji pada Gambar 1. Pada soal tersebut siswa diminta untuk menganalisis persamaan berdasarkan variabel-variabel yang berpengaruh terhdap kalor. Untuk dapat menjawab soal tersebut, siswa harus dapat (1) memahami hubungan kesebandingan antara besaran yang 
terpisah dengan tanda sama dengan (=), (2) memahami hubungan berbanding terbalik antara besaran yang berada pada posisi yang sama di salah satu bagian.

7. Telah diketahui bahwa persamaan kalor adalah $\mathrm{Q}=\mathrm{m} . \mathrm{c} . \Delta \mathrm{T}$. Berdasarkan persamaan tersebut pernyataan yang benar adalah ....

A. Pada bahan yang sama, pemberian kalor berbanding terbalik dengan peningkatan suhu

B. Pada bahan yang sama, pemberian kalor sebanding dengan penurunan suhu

C. Kalor jenis zat sebanding dengan perubahan suhu

D. Kalor jenis zat berbanding terbalik dengan suhu

E. Kalor berbanding terbalik dengan massa

Gambar 1. Butir soal untuk mengungkap pemahaman siswa tentang persamaan kalor dan maknanya

Presentase jawaban siswa setiap pilihan jawaban tersaji pada Tabel 3. Berdasarkan hasil analisis pada Tabel 3, terdapat 29 siswa $(80,5 \%)$ yang mampu menjawab dengan benar. Hanya sedikit yang menjawab salah, ini berarti bahwa sebagaian besar siswa telah mampu memahami persamaan kalor baik secara konsep maupun persamaan dan maknanya.

Tabel 3. Distribusi jawaban siswa terkait pertanyaan pada Gambar 1

\begin{tabular}{ccc}
\hline Pilihan & \multicolumn{2}{c}{ Keseluruhan Siswa } \\
& $\mathrm{N}$ & $\%$ \\
\hline $\mathrm{A}$ & 1 & 2,8 \\
$\mathrm{~B}$ & 2 & 5,6 \\
$\mathrm{C}$ & 4 & 11,1 \\
$\mathrm{D}^{*}$ & 29 & 80,5 \\
$\mathrm{E}$ & 0 & 0 \\
Total & 36 & 100 \\
\hline \multicolumn{3}{c}{${ }^{*}$ pilihan jawaban benar }
\end{tabular}

Terdapat 7 siswa (19,5\%) yang menjawab salah dalam soal ini. Siswa yang menjawab salah menunjukkan bahwa mereka hanya melihat rumus tanpa memahami maknanya. Hal ini sejalan dengan penelitian Taqwa, Priyadi, \& Rivaldo (2019) yang menyatakan bahwa sebagian besar responden lebih berorientasi pada rumus fisika dengan minim pemahaman tentang makna fisisnya.

\section{Pemahaman Siswa tentang Kalor Jenis Logam yang Terbaik untuk Bahan Penyerap Kalor}

Butir soal untuk mengakses pemahaman siswa terkait bahan terbaik untuk heatsink sebagai penyerap kalor tersaji pada Gambar 2. Untuk menjawab soal ini, siswa harus mampu (1) memahami kalor jenis berbanding terbalik dengan perubahan suhu, yang artinya semakin kecil nilainya semakin baik dalam mentransfer panas agar processor memiliki suhu tetap stabil, (2) Memahami konsep kesebandingan dan berbanding terbalik antar besaran dalam persamaan $\mathrm{Q}=$ m.c. $\Delta \mathrm{T}$, (3) memahami tentang variabel bebas, terikat dan kontrol saat menjawab pertanyaan model ini. 
11. Berikut ini adalah beberapa nilai kalor jenis logam

\begin{tabular}{|c|c|c|}
\hline No. & Jenis Bahan & Kalor jenis $\left(\mathbf{J} / \mathbf{k g}{ }^{\circ} \mathbf{C}\right)$ \\
\hline 1. & Udara & 1000 \\
\hline 2. & Besi & 460 \\
\hline 3. & Emas & 130 \\
\hline 4. & Tembaga & 390 \\
\hline 5. & Kuningan & 370 \\
\hline 6. & Timah Hitam & 130 \\
\hline
\end{tabular}

Berdasarkan tabel nilai diatas, maka bahan heatsink atau penyerap panas yang paling baik dan relatif terjangkau adalah ...
A. Besi
B. Emas
C. Timah Hitam
D. Tembaga
E. Kuningan

Gambar 2. Butir soal untuk mengungkap pemahaman siswa tentang bahan yang terbaik untuk heatsink

Distribusi jawaban siswa untuk pertanyaan ini tersaji pada Tabel 3 . Terdapat 25 siswa (sekitar 69\%) yang mampu menjawab dengan benar. Pilihan jawaban salah terbanyak terletak pada pilihan jawaban D yaitu 8 siswa (sekitar 22\%). Ini berarti bahwa siswa masih menggabungkan pemahaman mereka saat di kehidupan sehari-hari atau saat bongkar pasang CPU. Dimana di dalam CPU umumnya menggunakan heatsink yang terbuat dari tembaga atau aluminium.

Tabel 4. Distribusi jawaban siswa terkait pertanyaan pada Gambar 2

\begin{tabular}{ccc}
\hline Pilihan & \multicolumn{2}{c}{ Keseluruhan Siswa } \\
& $\mathrm{N}$ & $\%$ \\
\hline $\mathrm{A}$ & 1 & 2,8 \\
$\mathrm{~B}$ & 0 & 0 \\
$\mathrm{C}^{*}$ & 25 & 69,4 \\
$\mathrm{D}$ & 8 & 22,2 \\
$\mathrm{E}$ & 2 & 5,6 \\
Total & 36 & 100 \\
\hline \multicolumn{3}{c}{${ }^{*}$ pilihan jawaban benar }
\end{tabular}

Temuan ini pada dasarnya menunjukkan bahwa mereka para siswa yang menjawab salah memiliki kelemahan dalam melakukan interpretasi terkait konsep kalor jenis yang dikaitkan dengan makna fisisnya (Taqwa, Priyadi, \& Rivaldo, 2019). Terlebih lagi konsep ini dikaitkan dengan komputer yang menjadi keahlian siswa. Tentu mereka seharusnya dapat memahami dan memprediksi kondisi terbaik yang harus dipilih dalam melakukan perakitan komputer berdasarkan ilmu dasar fisika ini.

\section{Pemahaman Siswa Terkait Jenis Perpindahan Kalor dan Dampaknya di Komputer (CPU)}

Butir soal untuk mengakses pemahaman siswa terkait jenis perpindahan kalor dan dampaknya pada CPU diakses melalui soal nomor 12. Butir soal nomor 12 tersaji pada Gambar 3. Distribusi jawaban siswa terkait soal nomor 12 tersaji pada Tabel 5. Untuk dapat menjawab soal ini, siswa harus dapat: (1) memahami prinsip perpindahan kalor secara konveksi yaitu perpindahan kalor disertai zat-zatnya (mengalir), (2) membedakan karakteristik perpindahan kalor secara radiasi, konveksi, dan konduksi. Sebagian besar siswa mampu menjawab dengan benar menunjukkan bahwa pemahaman mereka terkait jenis perpindahan kalor di CPU dan dampaknya telah dikuasai dengan baik. 
12. Perhatikan gambar sirkulasi udara dalam CPU berikut ini

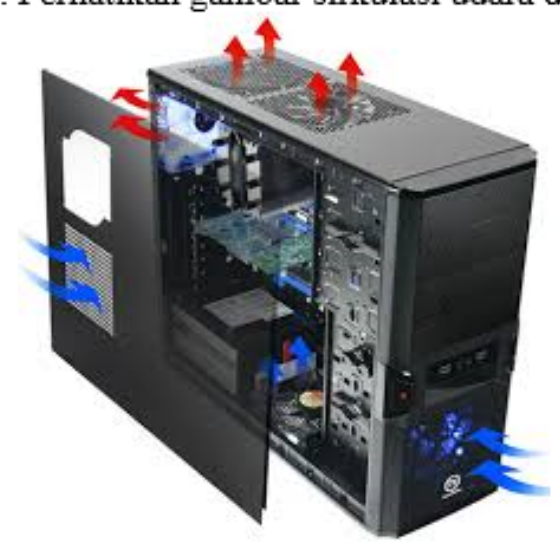

Berdasarkan konsep aliran udara tersebut, panas akan berpindah secara ... yang dipengaruhi beberapa factor antara lain suhu di luar CPU. Apabila suhu di luar CPU lebih dingin (Ruangan Ber-AC) maka, suhu CPU akan cenderung ... sehingga kondisi CPU relative lebih stabil.
A. Konduksi, rendah
B. Konduksi, tinggi
C. Konveksi, rendah
D. Konveksi, tinggi
E. Radiasi, tinggi.

Gambar 3. Butir soal untuk mengungkap pemahaman siswa tentang jenis perpindahan kalor dan dampaknya

Berdasarkan hasil analisis Tabel 5 menunjukkan bahwa sebagian besar siswa telah memahami jenis perpindahan kalor dan dampaknya dalam CPU. Terdapat $77,8 \%$ siswa yang berhasil menjawab pertanyaan butir soal ini. Sisanya yaitu $22,2 \%$ menjawab salah. Nampak bahwa pilihan jawab salah yang terbanyak dipilih siswa adalah A. Siswa yang menjawab pilihan jawaban ini memiliki pemahaman yang salah terkait konduksi.

Tabel 5. Distribusi jawaban siswa terkait pertanyaan pada Gambar 3

\begin{tabular}{ccc}
\hline Pilihan & \multicolumn{2}{c}{ Keseluruhan Siswa } \\
& $\mathrm{N}$ & $\%$ \\
\hline $\mathrm{A}$ & 5 & 13,8 \\
$\mathrm{~B}$ & 1 & 2,8 \\
$\mathrm{C}^{*}$ & 28 & 77,8 \\
$\mathrm{D}$ & 2 & 5,6 \\
$\mathrm{E}$ & 0 & 0 \\
Total & 36 & 100 \\
\hline \multicolumn{3}{c}{ * pilihan jawaban benar }
\end{tabular}

Siswa yang menjawab benar menunjukkan bahwa siswa benar-benar dapat memahami konsep perpindahan kalor baik secara teori dan praktiknya dalam bidang TKJ. Serta yang tak kalah penting yaitu siswa mengetahui manfaat daripada perpindahan kalor jenis ini dalam mendukung sistem komputer berjalan dengan optimal. Proses perpindahan kalor secara konveksi dalam komputer sejatinya merupakan jenis konveksi paksa. Konveksi paksa berguna untuk mengalirkan udara dengan tenaga dari luar (Supu, dkk, 2016). 


\section{Pemahaman Siswa Tentang Ilmu Troubleshooting yang Berkaitan dengan Perpindahan Kalor}

Soal untuk mengungkap pemahaman siswa terkait ilmu troubleshooting atau permasalahan pada bidang komputer diakses melalui butir soal nomor 13Untuk dapat menjawab pertanyaan tersebut terkait permasalahan perangkat komputer yang secara tibatiba mati atau restart sendiri, siswa harus memiliki pengetahuan tentang beberapa hal. Beberapa hal tersebut adalah (1) memahami bahwa processor yang bekerja pasti akan menghasilkan kalor (panas), (2) pasta processor sangat diperlukan untuk memperlancar transfer kalor dari processor ke heatsink, sehingga wajib dipastikan bahwa processor masih baik, (3) posisi heatsink wajib presisi dan rapat, agar tidak terdapat udara yang menjadi pengganti lapisan pasta processor, (4) kipas angin wajib aktif untuk memastikan aliran kalor dari processor ke heatsink, dari heatsink ke luar sistem pendingin processor, dan dari sistem pendingin processor ke luar CPU.

13. Salah satu permasalahan yang ada pada perangkat computer adalah computer off sendiri secara langsung saat pertama kali dinyalakan atau tiba-tiba computer melakukan restart. Menurut ilmu troubleshooting permasalahan yang terjadi adalah sebagai berikut ... (kecuali)
A. Pasta thermal kering
B. Kipas angin dibagian depan computer yang mengalirkan udara dingin mati
C. Pengunci heatsink kurang rapat, sehingga rongga antara heatsink dan processor tidak tertutup
D. Kipas diatas processor dan dibagian luar mati
E. Design casing CPU yang digunakan terlalu banyak celah

Gambar 4. Butir soal untuk mengungkap pemahaman siswa tentang troubleshooting yang berkaitan dengan konsep kalor

Distribusi jawaban siswa tersaji pada Tabel 6. Berdasarkan Tabel 6 nampak bahwa sebanyak 32 siswa (89\%) menjawab benar. Hanya 4 siswa (11\%) yang menjawab salah. Siswa yang menjawab salah menunjukkan bahwa dia belum secara tepat menguasai ilmu troubleshooting dalam CPU terutama yang berkaitan dengan dampak perpindahan kalor yang tidak optimal.

Tabel 6. Distribusi jawaban siswa terkait pertanyaan pada Gambar 4

\begin{tabular}{ccc}
\hline Pilihan & \multicolumn{2}{c}{ Keseluruhan Siswa } \\
& $\mathrm{N}$ & $\%$ \\
\hline $\mathrm{A}$ & 0 & 0 \\
$\mathrm{~B}$ & 4 & 11,1 \\
$\mathrm{C}$ & 0 & 0 \\
$\mathrm{D}$ & 0 & 0 \\
$\mathrm{E}^{\star}$ & 32 & 88,9 \\
Total & 36 & 100 \\
\hline \multicolumn{3}{c}{ *pilihan jawaban benar }
\end{tabular}

Pemahaman siswa terkait ilmu troubleshooting yang berkaitan langsung dengan materi suhu dan kalor sangat penting dikuasai siswa. Hal ini mengingat dengan penguasaan konsep dasar perpindahan kalor pada masing-masing posisi di CPU/Komputer siswa akan mampu menganalisis pilihan terbaik untuk mengoptimalkan proses tersebut. Kemampuan ini sangat mendukung dalam mengatasi berbagai permsalahan troubleshooting pada personal komputer (PC) baik gejala berat, sedang, maupun ringan (Ari, Sadjad, \& Suarga, 2014). 


\section{KESIMPULAN DAN SARAN}

Berdasarkan paparan hasil dan pembahasan yang telah diuraikan di atas, dapat disimpulkan bahwa sebagian besar siswa telah memahami konsep suhu, kalor dan aplikasinya dalam bidang komputer. Sebagain besar siswa telah mampu memahami persamaan kalor dan maknanya, jenis perpindahan kalor dan dampaknya, identifikasi permasalahan komputer yang berkaitan dengan kalor. Sedangkan pemahaman siswa terkait cara analisis data dalam pemilihan bahan yang terbaik untuk heatsink (penyerap kalor) masih perlu ditingkatkan.

Berdasarkan pemikiran hipotetik peneliti, ada beberapa kemungkinan penyebab siswa gagal memahami secara baik dalam beberapa soal tersebut. Pertama, mereka kesulitan dalam memahami konsep mana yang harus dipakai dalam masalah yang diberikan. Kedua, mereka masih menggunakan pengalaman sehari-harinya dalam menyelesaikan masalah soal yang dihadapinya, sehingga menyebabkan analisis terhadap data yang dihadapi tidak sepenuhnya dijalani. Perlu eksplorasi lebih mendalam terkait keterampilan troubleshooting PC seperti penelitian Widiastono, Banyal, \& Angriani, L. (2016) sekaligus dikolaborasikan dengan konsep sains yang mendukungnya seperti penelitian Mustofa (2019).

\section{DAFTAR PUSTAKA}

Ari, Sadjad, R. S., \& Suarga. (2014). Pascasarjana Universitas Hasanudin. Retrieved from Pasca Unhas: http://pasca.unhas.ac.id/jurnal/files/a754a26b91d6de242ceffb2b4aae3698.pdf

Alwan, A. A. (2011). Misconception of Heat and Temperature Among Physics Students. Procedia Social And Behavioral Science 12, 600-614.

Budi, E. M., Hendradjit, W., \& Budiman, A. (2010). Rekayasa Komputasional Sistem Pendingin Kluster Komputer. Jurnal Otomasi Kontrol dan Instrumentasi 2 (2), 97-104.

Firmansyah, B. (2009). Analisis Perpindahan Panas pada Pendingin CPU dengan Menggunakan Metode Elemen Hingga. Jurnal Rekayasa Mesin 9 (2), 25-29.

Gall, M. D., Gall, J. P., \& Borg, W. R. (2003). Educational Research: An Introduction Seventh Edition. USA: Pearson Education.

Kemdikbud. (2018). Struktur Kurikulum Sekolah Menengah Kejuruan (SMK) dan Madrasah Aliyah Kejuruan (MAK). Jakarta: Kementerian Pendidikan dan Kebudayaan RI.

Musdar, M. (2018). Pemetaan Konsep Fisika Siswa Kelas XI Pada Kurikulum 2013. Jurnal Pendidikan Fisika dan Keilmuan (JPFK) 4 (1), 36-41.

Mustofa, Z. (2016). Penerapan Pembelajaran STAD Berbantuan Multimedia untuk Meningkatkan Keaktifan dan Penguasaan Konsep Usaha-Energi. Seminar Nasional Fisika dan Pembelajarannya (pp. 643-647). Malang : Fisika UM.

Mustofa, Z. (2018). Pengaruh Multimedia Interaktif dalam Pembelajaran Remedial untuk Meningkatkan Prestasi Belajar Fisika. Teknodik 22 (2), 121-132.

Mustofa, Z. (2018). The Description of Student Understanding About Elasticity Concept. Jurnal Penelitian dan Pengembangan Pendidikan Fisika (JPPPF) 4 (1), 27-34.

Mustofa, Z. (2019). Pengaruh Discovery Learning Berbantuan E-Learning dalam Meningkatkan Penguasaan Konsep Siswa Tentang Konsentrasi Larutan dan Aplikasinya. Kwangsan 7 (1), 14-29.

Mustofa, Z., Sutopo, \& Mufti, N. (2016). Pemahaman Konsep Siswa SMA Tentang Usaha dan Energi Mekanik. Seminar Nasional Pendidikan IPA (pp. 519-528). Malang: Pascasarjana UM.

Supu Idawati, Usman Baso, Basri Selviani, Sunarmi. (2016). Pengaruh Suhu Terhadap Perpindahan Panas Pada Material yang Berbeda. Jurnal Dinamika 7 (1): 62-73

Taqwa M.R.A, Priyadi R, Rivaldo L. 2019. Pemahaman Konsep Suhu dan Kalor Mahasiswa Calon Guru. Jurnal Pendidikan Fisika 7 (1): 56-67

Triyuni. (2016). The Influence of Science Learning Set Using Scientific Approach and Problem Solving Model on Learning Outcomes of Junior High School Students in The Subject of Heat and Temperature. Jurnal Pendidikan IPA Indonesia 5 (2), 177-185. 
Widiastono, A., Banyal, N., \& Angriani, L. (2016). Sistem Informasi Troubleshooting Pada Personal Komputer (PC). ILKOM Jurnal Ilmiah, 8(2), 103-110. doi:https://doi.org/10.33096/ilkom.v8i2.53.103-110

Yuliana, Nabila. (2018). Penggunaan Model Pembelajaran Discovery Learning dalam Peningkatan Hasil Belajar Siswa di Sekolah Dasar. Jurnal IImiah Pendidikan dan Pembelajaran (JIPP) 2 (1), 21-29 